\title{
Taxonomic distinctness and conservation of a new high biodiversity subterranean area in Brazil
}

\author{
JONAS E. GALLÃO and MARIA ELINA BICHUETTE \\ Universidade Federal de São Carlos, Departamento de Ecologia e Biologia \\ Evolutiva, Laboratório de Estudos Subterrâneos, Rodovia Washington Luís, \\ Km 235, Campus São Carlos, 13565-905 São Carlos, SP, Brasil
}

Manuscript received on June 23, 2014; accepted for publication on July 29, 2014

\begin{abstract}
Subterranean environments, even though they do not possess a primary production (photosynthesis), may present high biodiversity, faunistic originality, endemism, phylogenetic isolations and unique ecological and/or evolution events, in addition to rare taxa. Studies investigating the biological diversity in Neotropical caves are relatively rare and recent, and most of them have been conducted in Brazil. We sampled caves from the state of Bahia, northeastern Brazil, and through sampling sufficiency tests and richness estimators, we demonstrate that the normatization for the Brazilian cave laws is not adequate for its conservation and that only $\alpha$ diversity index is not enough to verify faunistic patterns. We suggest that a phylogenetic diversity index be more robust and accurate for conservation purposes, particularly the Taxonomic Distinctness index. Moreover, we propose that the sandstone complex caves from Chapada Diamantina National Park need to be classified as being of high subterranean biodiversity in a global scope.
\end{abstract}

Key words: cave conservation, endemisms, faunistic singularity, speleological brazilian laws, troglobites.

\section{INTRODUCTION}

The subterranean environment comprises interconnected subsurface spaces that allow for the dispersion of species that inhabit there (Juberthie 2000). The hypogean realm presents faunistic originality and high endemism, as well as phylogenetic isolation (Gibert and Deharveng 2002) due to unique evolutionary events (Culver and Pipan 2009). Thus, some authors consider some subterranean systems as hotspots of biodiversity (e.g., Culver and Sket 2000, Deharveng 2005).

Nevertheless, Myers (1990) proposed the term "hotspots" based on floristic diversity. The term is

Correspondence to: Jonas Eduardo Gallão

E-mail: jonasgallao@usp.br not used here due to its falsifiability in environments that lack primary producers, which may include subterranean systems. Therefore, here we used a new term: "High Biodiversity Subterranean Area (HBSA)".

Cave populations can be divided into three ecological-evolutionary categories. Troglophiles (populations well established inside and outside of the caves); trogloxenes (populations inhabiting caves but must go out to complete their life cycles) and troglobites (exclusively and obligatory subterranean populations) (see Schiner 1854, Racovitza 1907, Barr 1968, Poulson and White 1969).

Troglobites generally present autapomorphic character states (troglomorphisms) related to the life in permanent darkness (Trajano 1993). 
The most known troglomorphisms are reduced or lack of eyes, elongated appendages and lighter coloration (Christiansen 1962). In general, troglobitic populations are specialized and fragile (Trajano and Bichuette 2006), and they need to be carefully considered in conservation programs.

Regarding the protection of Brazilian speleological patrimony, the current legislation (DECREE 6640 from November $7^{\text {th }} 2008$ ) regulates the use of natural subterranean cavities for environmental bids, classifying them by relevance level: maximum, high, medium and low. Only caves with maximum relevance are entirely protected from suppression.

To regulate this decree, Normative Instruction (NI) N. 2 from August $20^{\text {th }} 2009$ was published. In article 16 (paragraph 2) of this decree, some requirements of speleobiological studies were established, including the definition of the study period:

"Art. 16. The approval of speleological studies for classifying the relevance degree of natural subterranean caves is conditioned on the submission of sufficient information for the comprehension of the cave ecosystem. $\S 2^{\circ}$ The biological surveys must be completed in at least an annual cycle with at least two samplings per year, one occurring during the rainy season and the other during the dry season, aiming to minimally reveal the characteristics resulting from climatic seasonality."

In addition to the proposal of only two samplings during one annual cycle, many biologists use only alpha diversity indexes such as Shannon (H') in the environmental impact reports to determine the amount of protection, or total destruction, of Brazilian caves (M.E. Bichuette and J.E. Gallão pers. obs.). Although these indexes are useful in some ecological studies, they must be used with extreme caution and parsimony (Trajano et al. 2012).

Considering these issues, we tested some ecological concepts applied to biological cave conservation. We chose a region in northeastern Brazil with sandstone caves and a high diversity of cave animals. We attempted to answer the following questions: (1) Are two samplings enough to access the minimum richness of subterranean fauna and to detect faunistic patterns? (2) Are $\alpha$ diversity indexes suitable for cave conservation purposes/decisions?

\section{MATERIALS AND METHODS}

We conducted the study in 11 sandstone caves from Chapada Diamantina, central Bahia northeastern Brazil, belonging to Serra do Espinhaço and cut by the Paraguaçu rivers basins (Fig. 1).

Because some localities have only recently been discovered, or because access to those localities is difficult, the following caves were sampled once: Cantinho cave (Cac), Criminoso cave (Crc), Canal da Fumaça cave ( $\mathrm{CFc}$ ), Morro de Alvo cave (Mac), Veio de Aurélio cave (VAc), Cobras cave (Coc), and Lava Pé cave (LPc).

Rio dos Pombos cave (RPc), Ressuegência do Morro de Alvo cave (RMAc), and Torras System (TS) were sampled five times, and Parede Vermelha cave $(\mathrm{PVc})$ was sampled six times. The samples were collected through an extensive visual inspection in different substrates (humid places, walls and ceiling, soil, guano, under rocks and trunks), covering the maximum extension possible in all habitats.

We did not use pitfall traps because we did not wish to impact the subterranean populations (Sharratt et al. 2000) and because in these sandstones caves, the rocks are exposed and do not allow for the installation of pitfall traps. Regarding the aquatic fauna, we used hand nets and Surber traps. The collection effort totaled approximately eight hours per cave, always in three or four sessions. Chiropteran fauna were not studied.

In order to determine if the sampling was enough in relation to the given access, i.e the minimum species richness, Mao Tao and Jackknife first order sampling rarefaction curves were calculated for those caves in which we had more than three samples. The analyses were performed using EstimateS version 9.1 software (Cowell 2013). 
Studied caves in Chapada Diamantina region, Bahia State

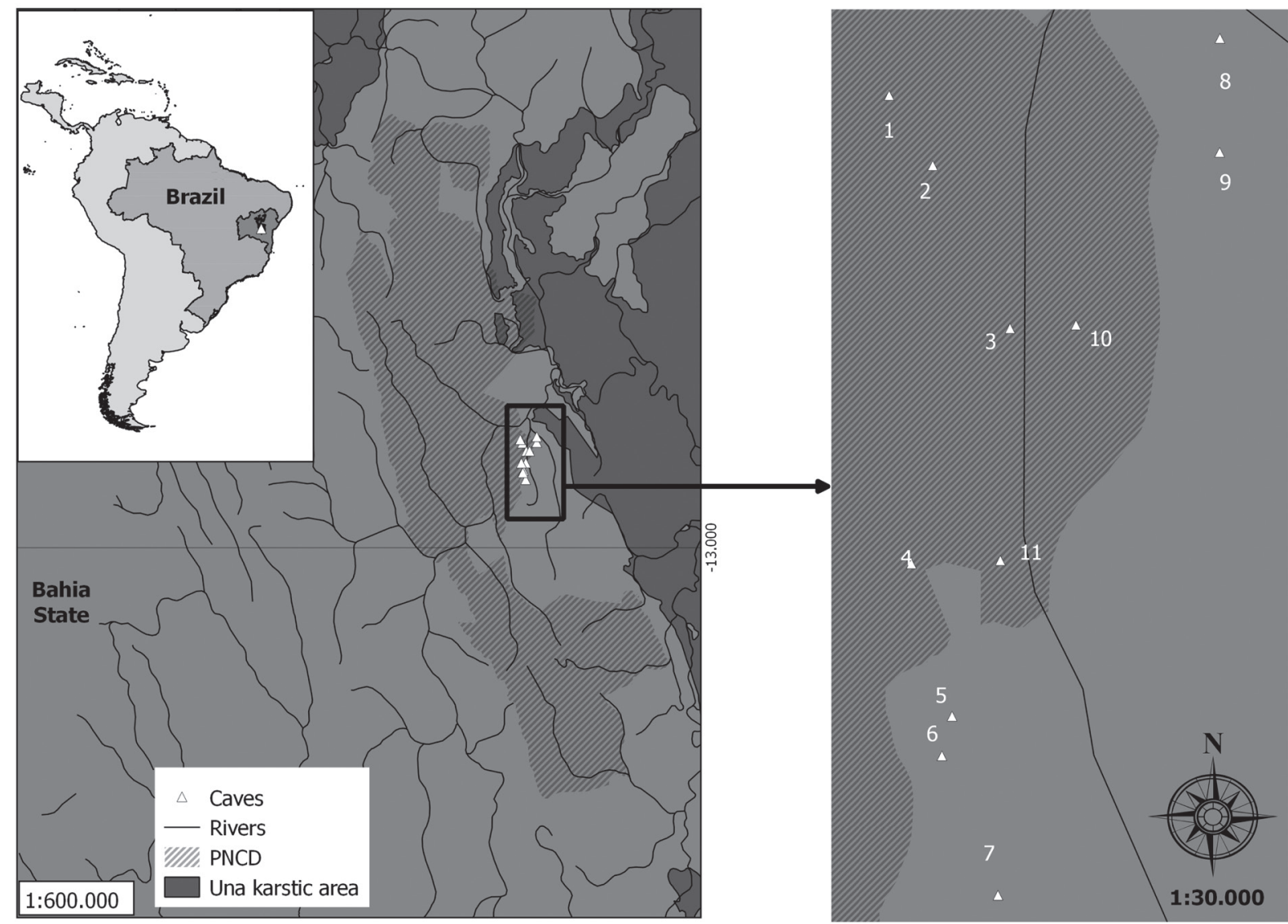

Figure 1 - Studied caves in the Chapada Diamantina region, state of Bahia. 1-Cantinho cave; 2-Criminoso cave; 3-Torras System; 4-Canal da Fumaça cave; 5-Rio dos Pombos cave; 6-Ressurgência do Morro de Alvo cave; 7-Morro de Alvo cave; 8-Veio de Aurélio cave; 9-Cobras cave; 10-Parede Vermelha cave; 11-Lava Pé cave. PNCD - Parque Nacional da Chapada Diamantina (National Park of Chapada Diamantina).

We also estimated the traditional Shannon (H') $\alpha$ diversity index, which is influenced by the sampling effort and requires the number of specimens (Clarke and Warwick 1998). These were calculated only for localities with more than three samples.

In addition, we calculated the Taxonomic Distinctness (TD) index and created a respective funnel graph for all sandstone caves because it is totally independent from the sampling effort (Warwick and Clarke 1998). All indexes were measured to determine which one would be the most robust in terms of cave conservation. The
$\mathrm{H}^{\prime}$ diversity index was calculated in Past version 2.13 (Hammer et al. 2001) and the TD index was calculated in R version 2.13.1 (2011).

Species that showed morphological troglomorphisms (mainly reduced or lack of eyes and/ or melanic pigmentation) but we were unsure as to whether they were real troglobites were left here only as troglomorphic species (TM in Appendix S1) (Supplementary Material). Of course, some of these troglomorphic species could change their status to troglobitic species, if we confirm its occurrence exclusive to caves. 


\section{RESULTS}

We recorded an abundance of 1,307 individuals distributed in 162 taxa (Appendix 1). Among them, 23 were troglobites and another 14 species exhibited some type of morphological troglomorphism. Besides 20 new species confirmed already (Appendix S1). PVc was the richest cave, with 13 troglobites.

The lower relative proportion of collected species after the second collection occasion was $40.0 \%$ for TS and, for the other three caves, more than half of the species were collected after the second sampling (Table I). Shannon's index (H') ranged from 2.753 (TS) to 3.459 (RPc), and the richest cave (PVc) had the third lowest H' of 2.983 (Table I).

\section{TABLE I}

Number of species, number and percentage of species after second collection for the caves with five or more collections and H' index. PVc - Parede Vermelha cave; RPc - Rio dos Pombos cave; RMAc - Ressurgência do Morro de Alvo cave; TS - Torras System. n - number of total species in each cave; A - number of species after second collection; \% percentage of species after second collection; TM3 - number of troglobitic and troglomorphic species after second collection. H' - Shannon index.

\begin{tabular}{cccccc}
\hline Caves & n & A & \% & TM3 & H' \\
\hline PVc & 64 & 35 & $(54.6 \%)$ & 10 & 2.983 \\
RPc & 54 & 42 & $(77.5 \%)$ & 10 & 3.459 \\
RMAc & 41 & 24 & $(58.5 \%)$ & 3 & 3.161 \\
TS & 20 & 8 & $(40.0 \%)$ & 2 & 2.753 \\
\hline
\end{tabular}

Furthermore, 25 troglobitic and troglomorphic species would have been neglected if the localities were sampled only twice (occasionally the same species occurred in different caves) (Table I).

Regarding the taxonomic distinctness, the expected $\Delta^{+}$was 67.985 (Fig. 2), and only two caves were below expectations; however, they were still inside the confidence interval. Six localities were above the expected $\Delta^{+}$and were in the funnel graph, and two caves were above the funnel graph: $\operatorname{MAc}\left(\Delta^{+} 85.286\right)$ and PVc $\left(\Delta^{+} 72.062\right)$.
The addition of species at each collection was almost a constant (Fig. 3), including the addition of troglobitic species after the second sampling, which is the limit in the current Brazilian legislation regarding Environmental Impact Assessments/ Environmental Impact Reports (EIA/RIMA from Portuguese). In addition to these species, we noted that in none of the cases, even in those cases with six samples (such as in the case of PVc), was the asymptote reached, indicating that the sampling is far from adequate with only two collections.

\section{DISCUSSION}

Diversity in subterranean environments is better expressed regionally than locally because many passages are accessible only to fauna (Sket 1999). Considering Igatu, there are 162 registered species and 23 are troglobites, which are distributed in a small area of only $25 \mathrm{~km}^{2}$. Among troglobites, this region is the type-locality of four troglobites (Discocyrtus pedrosoi Kury 2008. Glaphyropoma spinosum Bichuette, de Pinna and Trajano 2008. Troglorhopalurus translucidus Lourenço, Baptista and Giupponi 2004 and the first Brazilian troglobitic Mygalomorphae, Tmesiphantes hypogeus Bertani, Bichuette and Pedroso 2013), and it holds endemismics at a local, regional and zoogeographical scale as a new species of the troglobitic Verhoeffiella genus (Collembola), which previously only had a Paleartic distribution. However, the total number of troglobitic species may rise because some species exhibit some type of troglomorphic trait, which corroborates this hypothesis. The troglobitic catfish is already included on the IUCN Red List (Gallão and Bichuette 2012).

If we consider a local approach, PVc presented 13 troglobitic species, and there is a great possibility that this number will increase, which renders this cave of extreme importance for the Brazilian subterranean fauna because the Areias System, Alambari de Cima and Olhos d'Água caves 


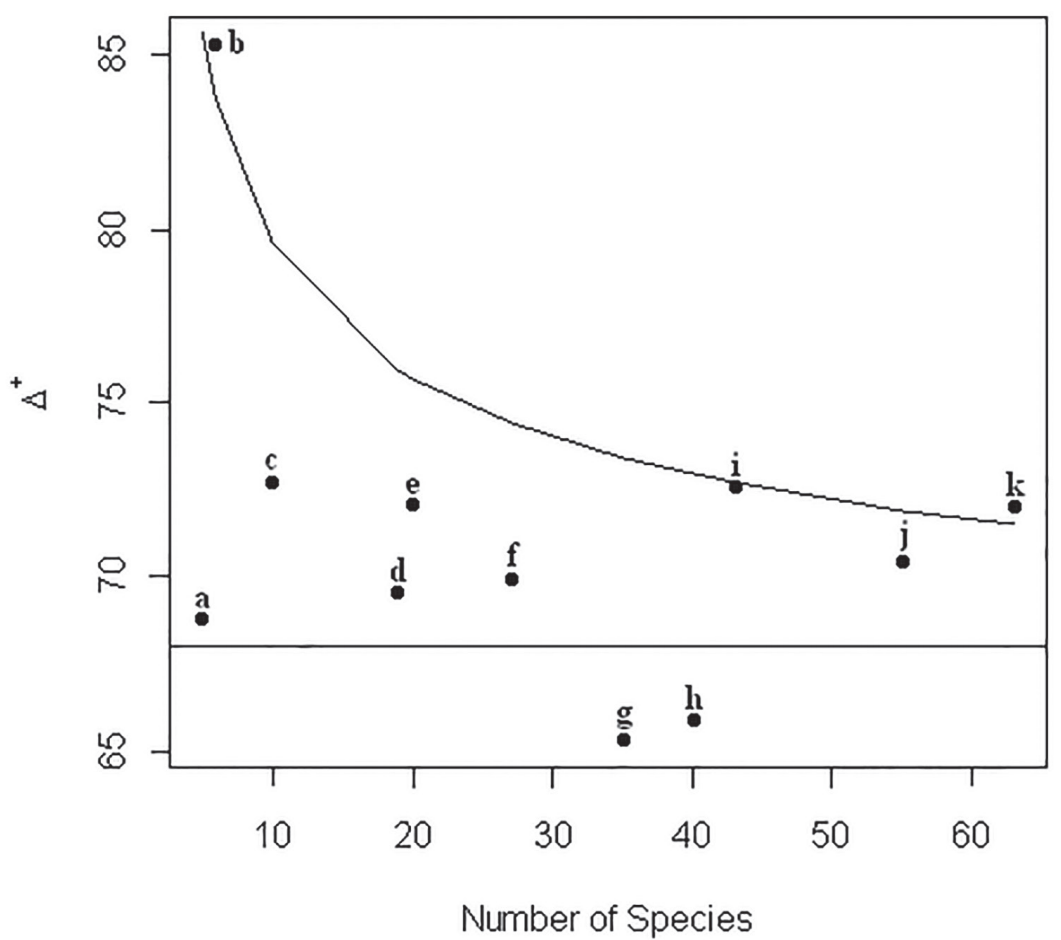

Figure 2 - Taxonomic distinctness of sandstone caves in Igatu and Lencóis. a-Cobras cave; b-Morro de Alvo cave; c-Criminoso cave; d-Veio de Aurélio cave; e-Torras System; f-Cantinho cave; g-Canal da Fumaça cave; h-Ressurgência do Morro de Alvo cave; i-Lava Pé cave; j-Rio dos Pombos cave; k-Parede Vermelha cave. $\Delta^{+}$ means Taxonomic Distinctness. Funnel graph means 95\% confidence limits.

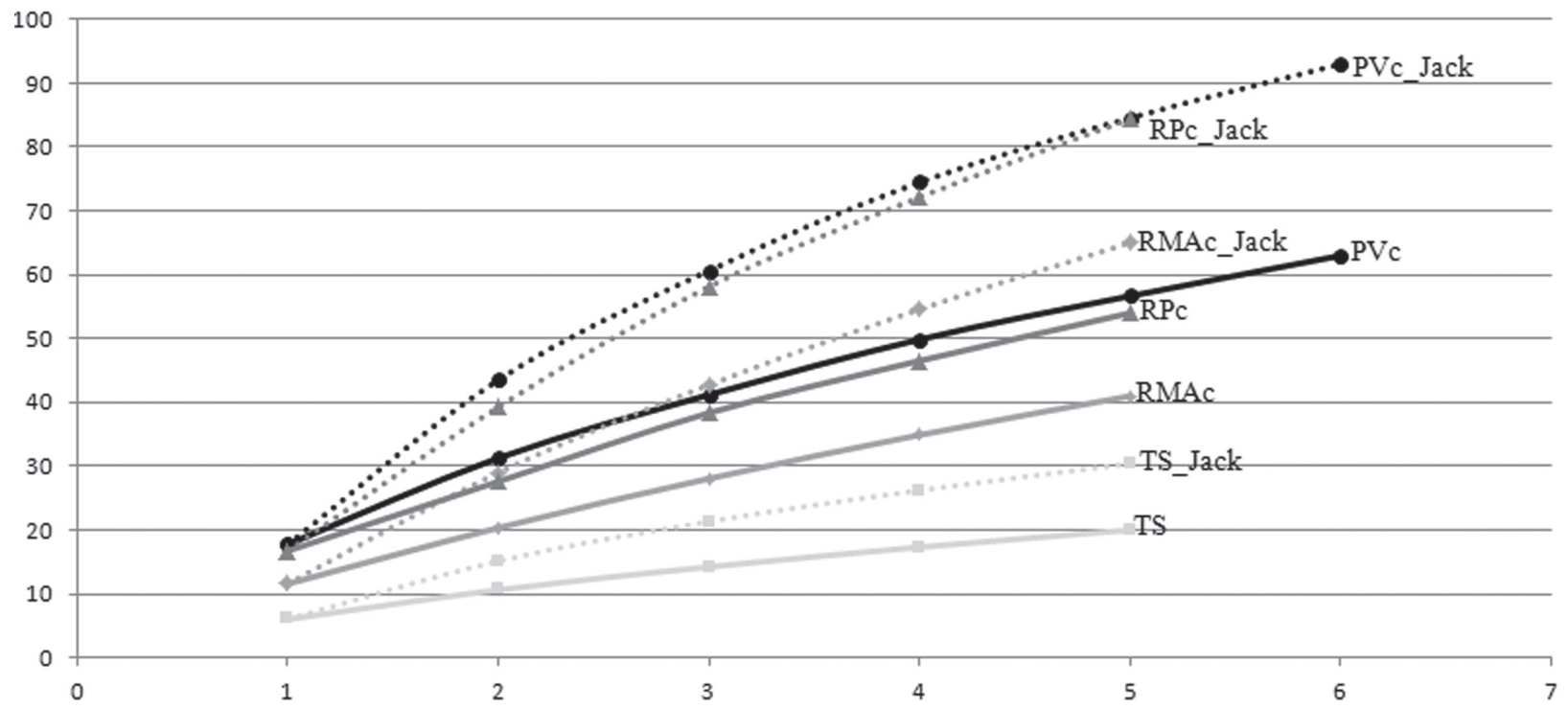

Figure 3 - Sampling rarefaction curves from caves with five or more collections and Jackknife first order estimator. PVc - Parede Vermelha cave; RPc - Rio dos Pombos cave; RMAc - Ressurgência do Morro de Alvo cave; TS - Torras System. For each cave, solid lines are Mao Tau sampling rarefaction curves and dashed lines are Jackknife first order richness estimator. Horizontal numbers means samples and vertical numbers means species. 
comprise 20, 10 and eight troglobites, respectively, and are considered Neotropical caves of high biodiversity relevance (Deharveng 2005, Trajano and Bichuette 2010).

Therefore, the sandstone caves from Chapada Diamantina represent a new Neotropical HBSA, under a local and regional focus.

As a consequence of incomplete sampling, species may be neglected, leading to erroneous estimations and resulting in incorrect decisions for management and conservation plans (Conroy and Noon 1996, Nichols et al. 1998). Two samples in an annual cycle, as proposed by Normative Instruction N. 2 for environmental bids, are absolutely insufficient to demonstrate faunistic patterns or even to determine the minimum species richness.

Corroborating this inadequacy, the rarefaction Mao Tau curves reveal that the asymptote is far from being achieved and that the addition of species in each collection event is a constant, including troglobitic or troglomorphic representatives (Fig. 3). This is in addition to the fact that at least $40 \%$ of species were registered starting from the third sampling occasion, as occurred in TS. However, it is worth noting that this cave is a huge duct tunnelshaped cave and is entirely washed out during each rainy season. For the other three tested caves, the percentage of species collected starting from the third sampling occasion was higher than $50 \%$.

Jackknife first order richness estimators were elevated, even for PVc, the only cave with six samples (Fig. 3). Thus, the survey of the Igatu caves is still not completely inclusive and two samplings are insufficient to assess the richness of a cave and to consequently classify its relevance levels.

Despite being elevated, these indeces, as Jackknife first order used here, may underestimate the real diversity. Any estimation that involves time and space does not reveal the differences in species composition in relation to time, collection period and different localities in the same habitat (Novotny 1993). Furthermore, propositions for habitat conservation must include both the observed richness and the number of species still undiscovered (Santos 2003).

According to the new Brazilian laws, troglobitic species are crucial to cave preservation or suppression. In this study, 25 troglobitic plus troglomorphic species would have been neglected (Table I) if only two samplings were used for environmental bids, which would certainly result in a decrease in the relevance of the sampled caves. Consequently, in this hypothetical situation, these caves could be suppressed. Trajano (2010) states that at least 10 samplings would be necessary, in distinct annual cycles, to begin to characterize subterranean environments; even after 20 samplings, new troglobitic species may still be found. To illustrate this requirement, in six karstic European regions, 190 samples were collected on average, and even after 100 samplings, troglobitic fauna was still being found (Culver and Pipan 2009).

The alpha diversity indeces were similar for the four localities (Table I), which do not reveal a faunistic singularity. Additionally, PVc had the third lowest H' of the four caves. If we took only this index as a basis for conservation purposes, PVc would most likely be neglected. This cave had a higher number of total and troglomorphic species, and its singularity was not reflected in the H' alpha diversity index.

Studies based only on alpha indeces that may or may not be mandatory for cave conservation must be used with extreme caution. Information about the identity of species, their phylogenetic relationships and other characteristics are lost due to the species' abundance and richness as well as their faunistic singularities, which are the main justification for the conservation of subterranean environments; these factors are minimized in numerical diversity values (Trajano et al. 2012).

Cianciaruso et al. (2009) affirm that the traditional indeces hide more than they reveal due to a great loss of information, and that such indeces are not sufficient for selecting locations, in 
this case caves, for conservation purposes (Sarkar 2006). Thus, it is inadvisable to use only $\alpha$ diversity indeces for biodiversity purposes, as occurs in advisory studies for cave suppression, which are not published because confidential contracts (M.E. Bichuette and J.E. Gallão pers. obs.).

We verify the high dispersion of points on the funnel graph (Fig. 2), which corroborates the faunistic singularity and the great phylogenetic diversity that exists in the Igatu caves.

Environments that are too degraded or polluted presenta low TD, which may produce points below the 95\% trust interval on the funnel graph (Warwick and Clarke 1998). Many caves of Chapada Diamantina were subjected in the past to heavy diamond mining, which continues in a residual, clandestine fashion at present (Bichuette et al. 2008). This activity could explain why the results were below expectations for some caves (Fig. 2).

Both caves that had points outside of the trust intervals were MAc and PVc, with six and 63 species, respectively. Despite its low richness in a single sample, MAc presented high phylogenetic diversity because all six species were distributed in four distinct classes, which explains the point outside of the trust interval. On the other hand, PVc presented a higher richness and a higher number of troglobites, items that also corroborate the presence of this cave outside the trust interval. All of the other caves are in the funnel graph and above expectations and corroborate the faunistic singularities found in the cave's biodiversity.

In conclusion, the Igatu region of central Bahia represents a HBSA for Brazil, as well as a Neotropical region and must be protected.

Two samplings, as stated in Brazilian laws for environmental bids, are insufficient for accessing the minimum richness of subterranean species and for predicting any pattern for subterranean fauna.

The traditional diversity index alone is not sufficient for conservation purposes, and we suggest other indeces, including those used for phylogenetic and functional diversity (Cianciaruso et al. 2009, Winter et al. 2013), as well as dark diversity (Partel et al. 2011).

\section{ACKNOWLEDGMENTS}

We thank our guides in Igatu, Mr. Raimundo Cruz dos Santos (Xiquinho) and Mr. Rafael Pires de Souza; the field helpers, Bianca Rantin, Luiza Simões, Tiago Scatolini, Gustavo Miranda and Alessandro Giupponi. Diego Monteiro von Schimonsky for providing the map and Gustavo Carvalho for helping with $\mathrm{R}$ program. We thank Fundação de Amparo à Pesquisa do Estado de São Paulo (FAPESP) for the grants to execute this work (processo 2008/05678-7); ICMBIO/SISBIO for collecting license (number 20165-1); PPGERN/ UFSCar for the infrastructure and part of financial support, Coordenação de Aperfeiçoamemto de Pessoal de Nível Superior (CAPES) for senior author's Masters scholarship, JEG. MEB thanks Conselho Nacional de Desenvolvimento Científico e Tecnológico for her productivity grants (CNPq 303715/2011-1). We also thanks the specialists A. Brescovit; A. Kury; R. Bertani; A. Giupponi; D. M. Schimonky; A. Chagas-Jr; C. Fernandes; J. Palácios-Vargas; D. Zeppelini; M. Bolfarini; F. Moreira; L. Prado; R. Falaschi; E. Caron and L. R. L. Simone. We thank three anonymous reviewers for valuable suggestions that improved the work.

\section{RESUMO}

Os ambientes subterrâneos, embora não possuam uma produção primária (fotossíntese), podem apresentar elevada biodiversidade, originalidade faunística, endemismos, isolamentos filogenéticos e eventos ecológicos e/ou evolutivos únicos, além de táxons raros. Estudos investigando a diversidade biológica em cavernas neotropicais são relativamente raros e recentes e, a maioria destes têm sido conduzidos no Brasil. Amostramos cavernas no estado da Bahia, 
nordeste do Brasil e, através de testes de suficiência amostral e estimadores de riqueza, demonstramos que a regulação das leis para cavernas brasileiras não é aplicável para conservação destas e que apenas índices de diversidade $\alpha$ não são suficientes para verificar padrões faunísticos. Sugerimos que um índice de diversidade filogenética é mais robusto e acurado para propostas de conservação, particularmente o índice de Distinção Taxonômica. Adicionalmente, propomos que o complexo de cavernas areníticas localizadas no Parque Nacional da Chapada Diamantina devem ser consideradas como de elevada biodiversidade subterrânea, em uma escala global.

Palavras-chave: conservação de cavernas, endemismos, singularidade faunística, Leis espeleológicas brasileira, troglóbios.

\section{REFERENCES}

BARR TC. 1968. Cave ecology and the evolution of troglobites. Evol Biol 2: 35-102.

Bertani R, Bichuette ME AND Pedroso DR. 2013. Tmesiphantes hypogeus sp. nov. (Araneae, Theraphosidae), the first troglobitic tarantula from Brazil. An Acad Bras Cienc 85: 235-243.

Bichuette ME, De Pinna MCC and Trajano E. 2008. A new species of Glaphyropoma: the first subterranean copionodontine catfish and the first occurrence of opercular odontodes in the subfamily (Siluriformes: Trichomycteridae). Neotrop Ichthyol 6: 301-306.

ChristiansEn KA. 1962. Proposition pour la classification des animaux cavernicoles. Spelunca 2: 76-78.

Cianciaruso MV, Silva IA AND BATAlHA MA. 2009. Phylogenetic and functional diversities: new approaches to community Ecology. Biota Neotrop 9: 93-103.

ClARKE KR AND WARWICK RM. 1998. A taxonomic distinctness index and its statistical properties. J Appl Ecol 35: 523-531.

CONROY MJ AND NOON BR. 1996. Mapping of species richness for conservation of biological diversity: Conceptual and methodological issues. Ecol Appl 6: 763-773.

COWELL RK. 2013. EstimateS. Statiscal estimation of species richness and shared species from samples.Version 9. Persistent URL < purl.oclc.org/estimates>.

Culver DC AND PIPAN T. 2009. Biology of Caves and Other Subterranean Habitats, $1^{\text {st }}$ ed., New York: Oxford University Press, USA, 254 p.

CUlver DC AND SKET B. 2000. Hotspots of Subterranean Biodiversity in Caves and Wells. J Cave Karst Stud 62: 11-17.
DeHARVEng L. 2005. Diversity patterns in the Tropics. In: CULVER DC AND WHITE WB (Eds), Encyclopedia of caves, Amsterdam: Elsevier Academic Press, p. 166-170.

GALLÃo JE AND BICHUETTE ME. 2012. The list of endangered fauna and impediments to inclusion of species - the example of Brazilian troglobitic fish. Nat Conservação 10: 83-87.

GIBERT J AND DEHARVENG L. 2002. Subterranean ecosystems: a truncated functional biodiversity. BioScience 52: 473481.

HAMMER Ø, HARPER DAT AND RYAN PD. 2001. PAST. Paleontological Statistics software package for education and data analysis. Paleontol Eletron 4: 9.

JuBERTHIE C. 2000. The diversity of the karstic and pseudokarstic hypogean habitats in the world. In: WILKENS H, CULVER DC AND HUMPHREYS WF (Eds), Ecosystems of the World, Subterranean Ecosystems, Amsterdam: Elsevier Academic Press, p. 17-39.

KURY AB. 2008. Two new troglomorphic Pachylinae (Opiliones, Laniatores, Gonyleptidae) from caves in Bahia, Brazil. Stud Neotrop Fauna E 43: 247-253.

LOURENÇO WR, BAPTISTA RLC AND GIUPPONI APL. 2004. Troglobitic scorpions: a new genus and species from Brazil. C R Biol 327: 1151-1156.

MYERS N. 1990. The biodiversity challenge: expanded hotspots analysis. The Environmentalist 10: 243-256.

Nichols JD, Boulinier T, Hines JE, POLlock KH AND SAUER JR. 1998. Inference methods for spatial variation in species richness and community composition when not all species are detected. Conserv Biol 12: 13901398.

Novotny V. 1993. Spatial and temporal components of species in Auchenorrhyncha (Insecta: Hemiptera) communities of Indochinese montane rain forest. J Trop Ecol 9: 93-100.

PARTEl M, Szava-Kovats R AND Zobel M. 2011. Dark diversity: shedding light on absent species. Trends Ecol Evol 26: 124-128.

POULSON TL AND White WB. 1969. The cave environment. Science 165: 971-980.

R Development Core Team. 2011. R: A language and environment for statistical computing. R Foundation for Statistical Computing, Vienna, Austria. ISBN 3-90005107-0, URL http://www.R-project.org/.

SANTOS AJ. 2003. Estimativas de Riqueza em Espécies. In: CULLEN Jr L, RUDRAN R AND VALLADARESPÁDUA C (Eds), Métodos de Estudos em Biologia da Conservação e Manejo da Vida Silvestre, Curitiba: Editora da Universidade Federal do Paraná, p. 19-41.

SARKAR S. 2006. Ecological diversity and biodiversity as concepts for conservation planning: comments on Ricotta. Acta Biotheor 54: 133-140.

RACOVITZA EG. 1907. Essai sur les problèmes biospéoloquies. Arch Zool Exp Gen 6: 371-488.

SCHINER JR. 1854. Fauna der Adelsberger-, Lueger- und Magdalen-Grotte. Verh Zool-Bot Ges Wien 3: 1-40. 
SHARRATT NJ, PICKER M AND SAMWAYS M. 2000. The invertebrate fauna of the sandstone of the caves of the Cape Peninsula (South Africa): patterns of endemism and conservation priorities. Biodivers Conserv 9: 107-143.

SKET B. 1999. The nature of biodiversity in hypogean waters and how it is endangered. Biodivers Conserv 8: 1319-1338.

Trajano E. 1993. A review of biospeleology in Brazil. Bol Soc Venez Espeleol 27: 18-23.

Trajano E. 2010. Política de conservação e critérios ambientais: princípios, conceitos e protocolos. Estud av 24: 135-146.

Trajano E AND Bichuette ME. 2006. Biologia Subterrânea: Introdução, $1^{\mathrm{a}}$ ed., São Paulo: Redespeleo, 92 p.

Trajano E And Bichuette ME. 2010. Diversity of Brazilian subterranean invertebrates, with a list of troglomorphic taxa. Subterr Biol 7: 1-16.

Trajano E Bichuette ME AND Batalha MA. 2012. Environmental studies in caves: the problems of sampling, identification, inclusion, and indices. EspeleoTema 23: 13-22.
WARWICK RM AND CLARKE KR. 1998. Taxonomic distinctness and environmental assessment. J Appl Ecol 35: 532-543.

Winter M, DEVICTOR V AND SCHWEIGER O. 2013. Phylogenetic diversity and nature conservation: where are we? Trends Ecol Evol 28: 199-204.

\section{SUPPLEMENTARY MATERIAL}

\section{APPENDIX S1}

Faunistic composition from Igatu/Andaraí, Chapada Diamantina, central Bahia, northeastern Brazil. Coc - Cobras cave; TS - Torras System; Crc - Criminoso cave; LPc - Lava Pé cave; Mac - Morro de Alvo cave; PVc - Parede Vermelha cave; RMAc - Ressurgência do Morro de Alvo cave; RPc Rio dos Pombos cave; CFc - Canal da Fumaça cave; Cac Cantinho cave; VAc - Veio de Aurélio cave; Troglobite taxa are outlined in bold; TM Troglomorphic. See main text for number off collections in each cave. 


\section{Supplementary Material}

\section{APPENDIX S1}

Faunistic composition from Igatu/Andaraí, Chapada Diamantina, central Bahia, northeastern Brazil. Coc - Cobras cave; TS - Torras System; Crc - Criminoso cave; LPc - Lava Pé cave; Mac - Morro de Alvo cave; PVc - Parede Vermelha cave; RMAc - Ressurgência do Morro de Alvo cave; RPc - Rio dos Pombos cave; CFc - Canal da Fumaça cave; Cac - Cantinho cave; VAc - Veio de Aurélio cave; Troglobite taxa are outlined in bold; TM Troglomorphic. See main text for number off collections in each cave.

\begin{tabular}{|c|c|c|c|c|c|c|c|c|c|c|c|}
\hline Taxa/Caves & Coc & TS & Crc & LPc & MAc & PVe & RMAc & RPc & CFe & Cac & VAc \\
\hline C. Secernentea & & & & $\mathrm{X}$ & & $\mathrm{X}$ & & & & & \\
\hline \multicolumn{12}{|l|}{ C. Turbellaria } \\
\hline \multicolumn{12}{|l|}{ O. Tricladida } \\
\hline Geoplanidae gen. 1 sp. 1 & & & & $\mathrm{X}$ & & & & & & & \\
\hline Geoplanidae gen. 1 sp. 2 & & & & $\mathrm{X}$ & & & & & & & \\
\hline Geoplanidae gen. 2 sp. 1 & & & & & & $\mathrm{X}$ & & & & & \\
\hline \multicolumn{12}{|l|}{ C. Annelida } \\
\hline \multicolumn{12}{|l|}{ Sc. Oligochaeta } \\
\hline \multicolumn{12}{|l|}{ O. Haplotaxida } \\
\hline Haplotaxidae gen. 1 sp. 1 & & & & & $\mathrm{X}$ & $\mathrm{X}$ & & $\mathrm{X}$ & & & \\
\hline \multicolumn{12}{|l|}{ C. Arachnida } \\
\hline Sc. Acari gen. $1 \mathrm{sp} .1^{\mathrm{TM}}$ & & & & & & $\mathrm{X}$ & & & & $\mathrm{X}$ & \\
\hline Sc. Acari gen. 2 sp. $1^{\mathrm{TM}}$ & & & & & & & & $\mathrm{X}$ & & & \\
\hline Sc. Acari gen. 3 sp. 1 & & & & & & & & $\mathrm{X}$ & & & \\
\hline O. Mesostigmata gen. 1 sp. 1 & & & & $\mathrm{X}$ & & & & & & & \\
\hline \multicolumn{12}{|l|}{ O. Parasitiformes } \\
\hline Opilioacaridae gen. 1 sp. 1 & & & & $\mathrm{X}$ & & $\mathrm{X}$ & & & & & \\
\hline \multicolumn{12}{|l|}{ O. Araneae } \\
\hline \multicolumn{12}{|l|}{ Mygalomorphae } \\
\hline Guyruita atlantica Guadanucci et al. 2007 & & & & & & $\mathrm{X}$ & & & & & \\
\hline Tmesiphantes hypogeus Bertani et al. 2013 & $\mathrm{X}$ & & & & & $\mathrm{X}$ & & & & & \\
\hline \multicolumn{12}{|l|}{ Araneomorphae } \\
\hline Amaurobiidae gen. 1 sp. 1 & & & & & & & $\mathrm{X}$ & & & & \\
\hline Anapidae gen. 1 sp. 1 & & & & & & $\mathrm{X}$ & & & & & \\
\hline Pseudanops sp. & & & & & & & & $\mathrm{X}$ & & & \\
\hline \multicolumn{12}{|l|}{ Araneidae } \\
\hline Alpaida sp. & & & & & & & & & $\mathrm{X}$ & & \\
\hline Corinnidae gen. 1 sp. 1 & & & & & & $\mathrm{X}$ & $\mathrm{X}$ & & & & \\
\hline Creugas sp. & & & & & & & & $\mathrm{X}$ & & $\mathrm{X}$ & \\
\hline \multicolumn{12}{|l|}{ Ctenidae } \\
\hline Ctenus sp. & & $\mathrm{X}$ & & & & & & $\mathrm{X}$ & & & \\
\hline Ctenus gr. ornatus & & & & & & & & & $\mathrm{X}$ & & \\
\hline Isoctenus sp. n. 1 & & & & & & $\mathrm{X}$ & & & $\mathrm{X}$ & & \\
\hline Ochyroceratidae gen. 1 sp. n. 1 & & & & & & & & & & & $\mathrm{X}$ \\
\hline Ochyroceratidae gen. 2 sp. n. 1 & & & & & & & & & & $\mathrm{X}$ & \\
\hline Theotima sp. & & & & $\mathrm{X}$ & & & & & & $\mathrm{X}$ & \\
\hline Oonopidae gen. 1 sp. 1 & & & & & & & & & & $\mathrm{X}$ & \\
\hline Neotrops sp. & & & & & & & & $\mathrm{X}$ & $\mathrm{X}$ & & \\
\hline Palpimanidae gen. 1 sp. 1 & & & & $\mathrm{X}$ & & & & & & & \\
\hline Philodromidae gen. 1 sp. 1 & & & $\mathrm{X}$ & & $\mathrm{X}$ & & & & & & \\
\hline Pholcidae gen. 1 sp. 1 & & & & & & & $\mathrm{X}$ & & & & \\
\hline Mesabolivar sp. n. 1 & & & & $\mathrm{X}$ & & $\mathrm{X}$ & & $\mathrm{X}$ & $\mathrm{X}$ & & \\
\hline
\end{tabular}




\begin{tabular}{|c|c|c|c|c|c|c|c|c|c|c|c|}
\hline Taxa/Caves & Coc & TS & Cre & LPc & MAc & PVc & RMAc & RPc & CFc & Cac & VAc \\
\hline Mesabolivar sp. 2 & & & & & & & $\mathrm{X}$ & & $\mathrm{X}$ & & \\
\hline Metagonia sp. n. 1 & & & & & & & & $\mathrm{X}$ & & $\mathrm{X}$ & \\
\hline Prodidomidae gen. 1 sp. $1^{\mathrm{TM}}$ & & & & & & & & $\mathrm{X}$ & & & \\
\hline Scytodidae gen. 1 sp. 1 & & & & & & $\mathrm{X}$ & & & & & \\
\hline Scytodes sincora Rheims \& Brescovit 2009 & & & & $\mathrm{X}$ & & $\mathrm{X}$ & & & & & \\
\hline Scytodes sp. 1 & & & & & & & & & $\mathrm{X}$ & & \\
\hline \multicolumn{12}{|l|}{ Sicariidae } \\
\hline Loxosceles sp. n. 1 & & & & $\mathrm{X}$ & & & & & $\mathrm{X}$ & & \\
\hline Loxosceles sp. 2 & & & & $\mathrm{X}$ & & $\mathrm{X}$ & $\mathrm{X}$ & & $\mathrm{X}$ & & \\
\hline Sicarius sp. & & & & & & & & $\mathrm{X}$ & & & \\
\hline Tetragnathidae gen. 1 sp. 1 & & & & & & & & & $\mathrm{X}$ & & \\
\hline Theridiidae gen. $1 \mathrm{sp.} 1$ & & & & & & & & & & & $\mathrm{X}$ \\
\hline Latrodectus sp. & & & & & & $\mathrm{X}$ & & $\mathrm{X}$ & & & \\
\hline Theridion sp. & & & & & & $\mathrm{X}$ & & $\mathrm{X}$ & & & $\mathrm{X}$ \\
\hline Theridiosomatidae gen. 1 sp. 1 & & & & & & $\mathrm{X}$ & $\mathrm{X}$ & & & & \\
\hline Naatlo sp. & & & & & & & & $\mathrm{X}$ & & & \\
\hline Plato sp. 1 & & $\mathrm{X}$ & $\mathrm{X}$ & $\mathrm{X}$ & $\mathrm{X}$ & $\mathrm{X}$ & $\mathrm{X}$ & $\mathrm{X}$ & $\mathrm{X}$ & $\mathrm{X}$ & \\
\hline Plato sp. 2 & & & & & & & & $\mathrm{X}$ & & & \\
\hline \multicolumn{12}{|l|}{ O. Amblypygi } \\
\hline \multicolumn{12}{|l|}{ Charinidae } \\
\hline Charinus sp. 1 & & & & & & & & & & & $\mathrm{X}$ \\
\hline Charinus sp. 2 & $\mathrm{X}$ & $\mathrm{X}$ & & $\mathrm{X}$ & & $\mathrm{X}$ & & & & $\mathrm{X}$ & \\
\hline \multicolumn{12}{|l|}{ O. Scorpiones } \\
\hline \multicolumn{12}{|l|}{ Buthidae } \\
\hline Troglorhopalurus translucidus Lourenço et al. 2004 & & & & & & $\mathrm{X}$ & & & & & \\
\hline \multicolumn{12}{|l|}{ O. Palpigradi } \\
\hline Eukoenenidae gen. 1 sp. n. 1 & & & & $\mathrm{X}$ & & & & & & $\mathrm{X}$ & \\
\hline \multicolumn{12}{|l|}{ O. Pseudoscorpiones } \\
\hline \multicolumn{12}{|l|}{ Chernetidae } \\
\hline Spelaeochernes sp. n. & & & & & & $\mathrm{X}$ & & & & & \\
\hline Syarinidae gen. 1 sp. 1 & & & & $\mathrm{X}$ & & $\mathrm{X}$ & & & & $\mathrm{X}$ & \\
\hline Chtoniidae gen. 1 sp. 1 & & & & & & $\mathrm{X}$ & & & & $\mathrm{X}$ & \\
\hline \multicolumn{12}{|l|}{ O. Opiliones } \\
\hline \multicolumn{12}{|l|}{ Gonyleptidae } \\
\hline Pachylinae gen. n. 1 sp. n. 1 & & $\mathrm{X}$ & $\mathrm{X}$ & $\mathrm{X}$ & & $\mathrm{X}$ & $\mathrm{X}$ & $\mathrm{X}$ & $\mathrm{X}$ & & \\
\hline Pachylinae gen. n. 1 sp. n. 2 & $\mathrm{X}$ & & $\mathrm{X}$ & & & $\mathrm{X}$ & $\mathrm{X}$ & $\mathrm{X}$ & $\mathrm{X}$ & & $X$ \\
\hline Discocyrtus pedrosoi Kury 2008 & $\mathrm{X}$ & $\mathrm{X}$ & $\mathrm{X}$ & $\mathrm{X}$ & & $\mathrm{X}$ & $\mathrm{X}$ & $\mathrm{X}$ & $\mathrm{X}$ & & $\mathrm{X}$ \\
\hline Tricommatinae gen. 1 sp. n. 1 & & & & & & & & & & $\mathrm{X}$ & \\
\hline \multicolumn{12}{|l|}{ C. Symphyla } \\
\hline \multicolumn{12}{|l|}{ Scolopendrellidae } \\
\hline Symphyllela sp. $^{\mathrm{TM}}$ & & & & & & & & & & $\mathrm{X}$ & \\
\hline \multicolumn{12}{|l|}{ C. Chilopoda } \\
\hline \multicolumn{12}{|l|}{ O. Scutigeromorpha } \\
\hline \multicolumn{12}{|l|}{ Pselliodidae } \\
\hline Sphendenonema guildingii (Newport 1845) & & $\mathrm{X}$ & & $\mathrm{X}$ & & $\mathrm{X}$ & & & $\mathrm{X}$ & & \\
\hline \multicolumn{12}{|l|}{ O. Scolopendromorpha } \\
\hline \multicolumn{12}{|l|}{ Cryptopidae } \\
\hline Cryptopinae & & & & & & & & & & & \\
\hline Cryptops sp. n. 1 & & & & & & $\mathrm{X}$ & & & & & \\
\hline Scolopendridae gen. 1 sp. 1 & & & & & & & $\mathrm{X}$ & & & & \\
\hline Scolopendridae gen. 2 sp. $1^{\mathrm{TM}}$ & & & & & & $\mathrm{X}$ & & & & $\mathrm{X}$ & \\
\hline
\end{tabular}




\begin{tabular}{|c|c|c|c|c|c|c|c|c|c|c|c|}
\hline Taxa/Caves & Coc & TS & Cre & LPc & MAc & PVc & RMAc & RPc & CFe & Cac & VAc \\
\hline \multicolumn{12}{|l|}{ Scolopocryptopidae } \\
\hline \multicolumn{12}{|l|}{ Scolopocryptopinae } \\
\hline Scolopocryptops sp. n. 1 & & & & $\mathrm{X}$ & & & & $\mathrm{X}$ & & $\mathrm{X}$ & \\
\hline Scolopocryptops ferrugineus macrodon Kraepelin 1903 & & & & & & $\mathrm{X}$ & & & & & \\
\hline \multicolumn{12}{|l|}{ O. Geophilomorpha } \\
\hline Geophilidae gen. 1 sp. 1 & & & & & & $\mathrm{X}$ & & & & & \\
\hline \multicolumn{12}{|l|}{ C. Diplopoda } \\
\hline \multicolumn{12}{|l|}{ O. Spirostreptida } \\
\hline Pseudonannolenidae gen. 1 sp. 1 & & $\mathrm{X}$ & & $\mathrm{X}$ & & $\mathrm{X}$ & $\mathrm{X}$ & $\mathrm{X}$ & $\mathrm{X}$ & $\mathrm{X}$ & $\mathrm{X}$ \\
\hline Pseudonannolenidae gen. $2 \mathrm{sp} .1^{\mathrm{TM}}$ & & & & & & $\mathrm{X}$ & $\mathrm{X}$ & & & & \\
\hline \multicolumn{12}{|l|}{ O. Polydesmida } \\
\hline Oniscodesmidae gen. 1 sp. 1 & & & & & & $\mathrm{X}$ & & & & & \\
\hline Oniscodesmidae gen. 1 sp. 2 & & & & & & & & & & $\mathrm{X}$ & \\
\hline Pyrgodesmidae gen. 1 sp. 1 & & $\mathrm{X}$ & & & & & & $\mathrm{X}$ & & & \\
\hline \multicolumn{12}{|l|}{ C. Malacostraca } \\
\hline \multicolumn{12}{|l|}{ O. Isopoda } \\
\hline Philosciidae gen. 1 sp. 1 & & & & $\mathrm{X}$ & & & & & $\mathrm{X}$ & $\mathrm{X}$ & \\
\hline Philosciidae gen. 1 sp. $2^{\mathrm{TM}}$ & & & & & & $\mathrm{X}$ & & & & & \\
\hline Philosciidae gen. 1 sp. $3^{\mathrm{TM}}$ & & & & & & & & & & & $\mathrm{X}$ \\
\hline Philosciidae gen. 2 sp. $1^{\mathrm{TM}}$ & & & & & & $\mathrm{X}$ & & & & & \\
\hline Plathyartridae gen. 1 sp. 1 & & & & & & $\mathrm{X}$ & & $\mathrm{X}$ & & & \\
\hline Trichorhina sp. ${ }^{\mathrm{TM}}$ & & & & $\mathrm{X}$ & & & & $\mathrm{X}$ & & & \\
\hline \multicolumn{12}{|l|}{ C. Entognatha } \\
\hline \multicolumn{12}{|l|}{ O. Collembola } \\
\hline \multicolumn{12}{|l|}{ Dycirtomidae } \\
\hline Dycirtoma sp. & & & & & & & $\mathrm{X}$ & $\mathrm{X}$ & & & \\
\hline \multicolumn{12}{|l|}{ Entomobryidae } \\
\hline Verhoeffiella sp. n. 1 & & & & & & $\mathrm{X}$ & $\mathrm{X}$ & & & & \\
\hline Heteromurus sp. 1 & & & & & & & $\mathrm{X}$ & $\mathrm{X}$ & & $\mathrm{X}$ & $\mathrm{X}$ \\
\hline \multicolumn{12}{|l|}{ Paronellidae } \\
\hline Troglopedetes sp. 1 & & & & & & $\mathrm{X}$ & $\mathrm{X}$ & & & $\mathrm{X}$ & $\mathrm{X}$ \\
\hline Troglopedetes sp. 2 & & $\mathrm{X}$ & & & & $\mathrm{X}$ & & $\mathrm{X}$ & $\mathrm{X}$ & & \\
\hline Tomoceridae indet. & & & & $\mathrm{X}$ & & & & & & & \\
\hline \multicolumn{12}{|l|}{ O. Diplura } \\
\hline Projapygidae gen. $1 \mathrm{sp} .1^{\mathrm{TM}}$ & & & & & & & & $\mathrm{X}$ & & & \\
\hline \multicolumn{12}{|l|}{ C. Insecta } \\
\hline \multicolumn{12}{|l|}{ O. Zygentoma } \\
\hline Nicoletiidae gen. 1 sp. 1 & & & & & & & & & $\mathrm{X}$ & & \\
\hline \multicolumn{12}{|l|}{ O. Odonata } \\
\hline So. Zygoptera gen. 1 sp. 1 & & $\mathrm{X}$ & & & & $\mathrm{X}$ & & & $\mathrm{X}$ & & \\
\hline O. Orthoptera & & & & & & & & & & & \\
\hline Gryllidae gen. 1 sp. 1 & & & $\mathrm{X}$ & & & $\mathrm{X}$ & & & & & \\
\hline Phalangopsidae gen. 1 sp. 1 & & & & & & & & $\mathrm{X}$ & & & \\
\hline Endecous sp. n. 1 & & $\mathrm{X}$ & & $\mathrm{X}$ & $\mathrm{X}$ & $\mathrm{X}$ & & & $\mathrm{X}$ & & \\
\hline Endecous sp. 2 & & $\mathrm{X}$ & & $\mathrm{X}$ & & & $\mathrm{X}$ & $\mathrm{X}$ & $\mathrm{X}$ & $\mathrm{X}$ & \\
\hline Eidmanacris sp. & & & & & & & $\mathrm{X}$ & & & & \\
\hline O. Blattaria & & & & & & & & & & & \\
\hline Blattellidae gen. 1 sp. $1^{\mathrm{TM}}$ & & & $\mathrm{X}$ & & & $\mathrm{X}$ & & & & $\mathrm{X}$ & $\mathrm{X}$ \\
\hline Blattellidae gen. 2 sp. 1 & & & & & & & & $\mathrm{X}$ & & & \\
\hline Blattellidae gen. 2 sp. 2 & & & & & $\mathrm{X}$ & & & & & & \\
\hline O. Psocoptera gen. 1 sp. 1 & & & & & & $\mathrm{X}$ & & & & & \\
\hline
\end{tabular}




\begin{tabular}{|c|c|c|c|c|c|c|c|c|c|c|c|}
\hline Taxa/Caves & Coc & TS & Cre & LPc & MAc & PVc & RMAc & RPc & CFc & Cac & VAc \\
\hline O. Thysanoptera gen. $1 \mathrm{sp} .1$ & & & & & & & & $\mathrm{X}$ & & & \\
\hline \multicolumn{12}{|l|}{ O. Hemiptera } \\
\hline Cixiidae gen. 1 sp. 1 & & & & $\mathrm{X}$ & & $\mathrm{X}$ & $\mathrm{X}$ & $\mathrm{X}$ & $\mathrm{X}$ & $\mathrm{X}$ & $\mathrm{X}$ \\
\hline Cydnidae gen. 1 sp. 1 & & $\mathrm{X}$ & & & & $\mathrm{X}$ & & & $\mathrm{X}$ & & \\
\hline Pyrrhocoridae gen. 1 sp. 1 & & & & $\mathrm{X}$ & & & & & & & \\
\hline \multicolumn{12}{|l|}{ Reduviidae } \\
\hline Emesinae gen. 1 sp. 1 & & $\mathrm{X}$ & & & & & & $\mathrm{X}$ & $\mathrm{X}$ & & \\
\hline Emesinae gen. 2 sp. 1 & & & & $\mathrm{X}$ & & & & & & & \\
\hline Reduviinae gen. $1 \mathrm{sp} .1$ & & & & & & & & $\mathrm{X}$ & & & \\
\hline Veliidae gen. 1 sp. 1 & & & & & & $\mathrm{X}$ & & & $\mathrm{X}$ & $\mathrm{X}$ & \\
\hline Paravelia sp. n. 1 & & $\mathrm{X}$ & & $\mathrm{X}$ & & & & & & & $\mathrm{X}$ \\
\hline \multicolumn{12}{|l|}{ O. Hymenoptera } \\
\hline \multicolumn{12}{|l|}{ Diapriidae } \\
\hline Diapriinae gen. $1 \mathrm{sp} .1$ & & & & $\mathrm{X}$ & & & & & & & \\
\hline \multicolumn{12}{|l|}{ Formicidae } \\
\hline Atta sexdens & & & & & & $\mathrm{X}$ & & & & & \\
\hline Cephalotes bruchi (Forel 1912) & & & $\mathrm{X}$ & & & & & & & & \\
\hline Pheidole sp. 1 & & & & & & & $\mathrm{X}$ & & & & \\
\hline Solenopsis sp. 1 & & & & & & $\mathrm{X}$ & & & & & \\
\hline Solenopsis sp. 2 & & & & & & & $\mathrm{X}$ & $\mathrm{X}$ & $\mathrm{X}$ & & \\
\hline Solenopsis sp. 3 & & & & $\mathrm{X}$ & & $\mathrm{X}$ & $\mathrm{X}$ & & $\mathrm{X}$ & & $\mathrm{X}$ \\
\hline Solenopsis sp. 4 & & & & & & & $\mathrm{X}$ & & & & $\mathrm{X}$ \\
\hline \multicolumn{12}{|l|}{ Scelionidae } \\
\hline Scelioninae gen. 1 sp. 1 & & & & & & & & & & $\mathrm{X}$ & \\
\hline \multicolumn{12}{|l|}{ O. Coleoptera } \\
\hline Alleculidae gen. 1 sp. 1. & & & & & & $\mathrm{X}$ & & & & & \\
\hline Carabidae gen. 1 sp. 1 & & & & & & & & $\mathrm{X}$ & & & \\
\hline Carabidae gen. 1 sp. 2 & & & & & & & & $\mathrm{X}$ & & & \\
\hline Carabidae gen. 2 sp. 1 & & & & & & & & $\mathrm{X}$ & & & \\
\hline Carabidae gen. 3 sp. 1 & & & & $\mathrm{X}$ & & & & & & & \\
\hline Curculionidae gen. 1 sp. 1 & & & & & & $\mathrm{X}$ & & $\mathrm{X}$ & & $\mathrm{X}$ & \\
\hline Curculionidae gen. 1 sp. 2 & & & & & & & & & & $\mathrm{X}$ & \\
\hline Curculionidae gen. 2 sp. 1 & & & & & & & & $\mathrm{X}$ & & & \\
\hline Elateridae gen. 1 sp. 1 & & & & & & & & $\mathrm{X}$ & & & \\
\hline \multicolumn{12}{|l|}{ Elmidae } \\
\hline Macrelmis sp. 1 & & & & & & & $\mathrm{X}$ & & & & \\
\hline Macrelmis sp. 2 & & & & & & & $\mathrm{X}$ & & & & \\
\hline Eucnemidae gen. 1 sp. 1 & & $\mathrm{X}$ & & & & & & & & & \\
\hline Dytiscidae gen. 1 sp. 1 & & & & & & & & $\mathrm{X}$ & $\mathrm{X}$ & & \\
\hline Ptilodactylidae gen. 1 sp. 1 & & & & & & $\mathrm{X}$ & & & & & \\
\hline Scarabaeidae gen. 1 sp. 1 & & & & & & & $\mathrm{X}$ & & & & \\
\hline Scarabaeidae gen. 1 sp. 2 & & & & $\mathrm{X}$ & & & & & & & \\
\hline Scarabaeinae gen. 1 sp. 1 & & & & $\mathrm{X}$ & & & & & & & \\
\hline Scarabaeinae gen. 2 sp. 1 & & & & & & & & $\mathrm{X}$ & & & \\
\hline \multicolumn{12}{|l|}{ Scirtidae } \\
\hline Scirtes sp. & & & & & & & $\mathrm{X}$ & & & $\mathrm{X}$ & \\
\hline Scydmaenidae gen. 1 sp. $1^{\mathrm{TM}}$ & & & & & & & & & & $\mathrm{X}$ & \\
\hline Staphylinidae gen. 1 sp. 1 & & & & $\mathrm{X}$ & & & $\mathrm{X}$ & & & & \\
\hline Staphylinidae gen. 1 sp. 2 & & & & & & & & $\mathrm{X}$ & $\mathrm{X}$ & & \\
\hline Aleocharinae gen. 1 sp. 1 & & & & $\mathrm{X}$ & & & $\mathrm{X}$ & & & & \\
\hline Paederinae gen. 1 sp. 1 & & & & & & & $\mathrm{X}$ & & & & \\
\hline
\end{tabular}




\begin{tabular}{|c|c|c|c|c|c|c|c|c|c|c|c|}
\hline Taxa/Caves & Coc & TS & Cre & LPc & MAc & PVc & RMAc & RPc & CFc & Cac & VAc \\
\hline Paederinae gen. 1 sp. 2 & & & & & & & & & & & $\mathrm{X}$ \\
\hline Paederinae gen. 1 sp. 3 & & & & & & & $\mathrm{X}$ & & & & \\
\hline Homaeotarsus sp. & & & & & & $\mathrm{X}$ & $\mathrm{X}$ & & & & \\
\hline Pselaphinae gen. 1 sp. $1^{\mathrm{TM}}$ & & & & & & $\mathrm{X}$ & & & & & \\
\hline Pselaphinae gen. 2 sp. 1 & & & & & & $\mathrm{X}$ & & & & & \\
\hline Pselaphinae gen. 2 sp. 2 & & & & & & & & & $\mathrm{X}$ & & \\
\hline Pselaphinae gen. $3 \mathrm{sp} .1^{\mathrm{TM}}$ & & & & & & & & & $\mathrm{X}$ & & \\
\hline \multicolumn{12}{|l|}{ O. Diptera } \\
\hline Cecidomyiidae gen. 1 sp. 1 & & & & & & $\mathrm{X}$ & & & & & $\mathrm{X}$ \\
\hline Chaoboridae gen. 1 sp. 1 & & & & & & & $\mathrm{X}$ & & & & \\
\hline Chironomidae gen. 1 sp. 1 & & & & & & $X$ & $X$ & & & & \\
\hline Hippoboscidae gen. 1 sp. 1 & & $\mathrm{X}$ & & & & & & & & & \\
\hline \multicolumn{12}{|l|}{ Keroplatidae } \\
\hline Keroplatinae gen. 1 sp. n. 1 & & & & $\mathrm{X}$ & & & $\mathrm{X}$ & & $\mathrm{X}$ & $\mathrm{X}$ & \\
\hline Limoniidae gen. 1 sp. 1 & & $\mathrm{X}$ & & & & & $\mathrm{X}$ & $\mathrm{X}$ & & & $\mathrm{X}$ \\
\hline Muscidae gen. 1 sp. 1 & & & & $\mathrm{X}$ & & & & & & & \\
\hline \multicolumn{12}{|l|}{ Psychodidae } \\
\hline Phlebotominae gen. 1 sp. 1 & & & & $X$ & & & & & & & \\
\hline Sciaridae gen. 1 sp. 1 & & & & & & $\mathrm{X}$ & $\mathrm{X}$ & $\mathrm{X}$ & & & \\
\hline Simuliidae gen. 1 sp. 1 & & & & & & & & $\mathrm{X}$ & & & \\
\hline Tipulidae gen. 1 sp. 1 & & & & & & & $\mathrm{X}$ & & & & \\
\hline \multicolumn{12}{|l|}{ O. Lepidoptera } \\
\hline Tineidae gen. 1 sp. 1 & & & & $\mathrm{X}$ & & $\mathrm{X}$ & & $\mathrm{X}$ & $\mathrm{X}$ & & \\
\hline \multicolumn{12}{|l|}{ O. Trichoptera } \\
\hline Hidropsychidae gen. 1 sp. 1 & & & & & & & & $\mathrm{X}$ & & & \\
\hline \multicolumn{12}{|l|}{ C. Gastropoda } \\
\hline \multicolumn{12}{|l|}{ O. Pulmonata } \\
\hline \multicolumn{12}{|l|}{ Subulinidae } \\
\hline Obeliscinae gen. 1 sp. 1 & & & & $\mathrm{X}$ & & & & $\mathrm{X}$ & & & \\
\hline \multicolumn{12}{|l|}{ Systrophiidae } \\
\hline Happia sp. n. 1 & & & & $\mathrm{X}$ & & $\mathrm{X}$ & & $\mathrm{X}$ & $\mathrm{X}$ & & \\
\hline Happia sp. n. 2 & & & & & & & & & & $\mathrm{X}$ & \\
\hline \multicolumn{12}{|l|}{ C. Actinopterygii } \\
\hline \multicolumn{12}{|l|}{ O. Siluriformes } \\
\hline \multicolumn{12}{|l|}{ Trichomycteridae } \\
\hline Copionodon sp. $\mathbf{n}$. & $\mathrm{X}$ & $\mathrm{X}$ & $\mathrm{X}$ & & $\mathrm{X}$ & $\mathrm{X}$ & $\mathrm{X}$ & $\mathrm{X}$ & & & $\mathrm{X}$ \\
\hline Glaphyropoma spinosum Bichuette et al. 2008 & & $\mathrm{X}$ & $\mathrm{X}$ & & & $\mathrm{X}$ & $\mathrm{X}$ & $\mathrm{X}$ & & & \\
\hline
\end{tabular}

